\title{
PENGARUH PELATIHAN SCISSOR JUMP DAN SINGLE LEG SPEED HOPE DENGAN TINGKAT KECEPATAN BERBEDA TERHADAP DAYA LEDAK OTOT TUNGKAI PADA PESERTA EKSTRAKURIKULER BULUTANGKIS
}

\author{
Ni Made Arnitayani ${ }^{1}$, I Wayan Artanayasa ${ }^{2}$, Syarif Hidayat ${ }^{3}$ \\ ${ }^{1}$ Program Studi Pendidikan Olahraga, Program Pascasarjana Universitas Pendidikan Ganesha, \\ Singaraja-Bali \\ ${ }^{2}$ Program Studi Penjaskesrek, Universitas Pendidikan Ganesha \\ Singaraja-Bali \\ ${ }^{3}$ Program Studi Pendidikan Kepelatihan Olahraga, Universitas Pendidikan Ganesha \\ Singaraja-Bali \\ e-mail: arnitayani833@gmail.com, wayan.artanayasa@undiksa.ac.id, \\ syarif.hidayat@undiksa.ac.id
}

\begin{abstract}
Abstrak
Penelitian ini bertujuan untuk menganalisis daya ledak otot tungkai yang diakibatkan dari: 1) Pengaruh latihan scissor jump yang memiliki tingkat kecepatan tinggi dan rendah. 2) Pengaruh latihan single leg speed hope yang memiliki tingkat kecepatan tinggi dan rendah. 3) Perbedaan antara pengaruh latihan scissor jump yang memiliki tingkat kecepatan tinggi dan rendah. 4) Perbedaan antara pengaruh latihan single leg speed hope yang memiliki tingkat kecepatan tinggi dan rendah. 5) Interaksi antara latihan scissor jump dan single leg speed hope. Jenis penelitian yang digunakan adalah eksperimen semu dengan rancangan treatment by level. Sampel yang digunakan berjumlah 48 orang. Teknik analisis data menggunakan anava 2 jalur pada taraf signifikansi 0,05 . Hasil penelitian menunjukkan latihan scissor jump yang memiliki tingkat kecepatan tinggi mempunyai perbedaan rata-rata pre test dan post test sebesar 19,33. Latihan scissor jump yang memiliki tingkat kecepatan rendah mempunyai perbedaan rata-rata pre test dan post test sebesar 18,67. Pengaruh latihan single leg speed hope yang memiliki tingkat kecepatan tinggi mempunyai perbedaan rata-rata pre test dan post test sebesar 8,67. Pengaruh latihan single leg speed hope yang memiliki tingkat kecepatan rendah mempunyai perbedaan rata-rata pre test dan post test sebesar 17,50. Perbedaan antara pengaruh latihan scissor jump yang memiliki tingkat kecepatan tinggi lebih unggul sebesar 15,000 dari tingkat kecepatan rendah dengan nilai signifikan 0,000 . Perbedaan antara pengaruh latihan single leg speed hope yang memiliki tingkat kecepatan tinggi lebih unggul sebesar 8,083 dari tingkat kecepatan rendah dengan nilai signifikan 0,000. Interaksi antara latihan scissor jumpdan single leg speed hope mempunyai nilai sig. $0,000<0,05$ sehingga terjadi interaksi. Perlu diadakannya penerapan pelatihan scissor jump yang lebih optimal untuk meningkatkan kekuatan otot dan daya ledak otot tungkai.
\end{abstract}

Kata-kata kunci: Pelatihan, Tingkat Kecepatan, Daya Ledak Otot Tungkai

\begin{abstract}
This study aims to analyze the explosive power of the leg muscles as a result of: 1) The effect of the scissor jump training which has a high and low speed level. 2) The effect of the single leg speed hope exercise which has high and low speed levels. 3) The difference between the effect of the scissor jump training which has a high and low speed level. 4) The difference between the effect of single leg speed hope training which has high and low speed levels. 5) The interaction between scissor jump exercise and single leg speed hope. This type of research is a quasi-experimental with a treatment by level design. The sample used was 48 people. The data analysis technique used 2-way ANOVA at a significance level of 0.05 . The results showed that the scissor jump exercise which has a high speed level has a difference in the average pre-test and post-test by 19.33. The scissor jump exercise which has a low speed level has a difference in the average pre-test and post-test of 18.67. The effect of single leg speed hope exercise which has a high speed level has a difference in the average pre test and post test of 8.67. The effect of the single leg speed hope exercise which has a low speed level has a difference in the average pre-test and post-test by 17.50. The difference between the effect of scissor jump training which has a
\end{abstract}


high speed level is superior to 15,000 from a low speed level with a significant value of 0,000. The difference between the effect of single leg speed hope exercise which has a high speed level is superior to 8,083 than the low speed level with a significant value of 0,000. The interaction between scissor jump exercise and single leg speed hope has a sig value. $0.000<0.05$ so that there is an interaction. It is necessary to implement a more optimal scissor jump training to increase muscle strength and leg muscle explosive power

Keywords :Exercise Method, Speed Level, Limb Muscle Explosive Power

\section{PENDAHULUAN}

Olahraga merupakan suatu aktivitas fisik untuk melakukan suatu gerakan secara sistematis agar tujuan yang diinginkan tercapai. Pergerakan-pergerakan komponen tubuh terutama otot dan sendi, sangat perlu diperhatikan dalam berolahraga. Salah satu cabang olahraga yang memerlukan kondisi fisik adalah cabang olahraga bulutangkis. Menurut(Dewi et al., 2018) Aspek kondisi fisik penting karena dalam permainan bulutangkis pemain harus melakukan gerakan yang kompleks, seperti meloncat, gerak cepat mengejar shuttlecock, memutar badan, Kondisi fisik yang baik harus dimiliki oleh setiap atlet atau olahragawan sesuai dengan aktivitas olahraga atau cabang olahraga yang ditekuninya. Daya ledak merupakan salah satu komponen-komponen dari kondisi fisik. Daya Ledak adalah kemampuan untuk melakukan aktivitas secara tiba-tiba dan cepat dengan mengerahkan seluruh kekuatan dalam waktu yang singkat (I. G. N. Nala, 2011)

Secara teoritis, pelatihan kondisi fisik akan memberikan manfaat yang lebih baik apabila diberikan pada masa adolesensi, karena masa adolesensi merupakan masa yang paling tepat dalam pencapaian kemampuan fisik yang optimal karena pada masa ini fungsi fisiologis tubuh mengalami perkembangan dengan kisaran umur 10 sampai 18 tahun untuk perempuan dan 12 sampai 20 tahun untuk laki-laki (Sugiyanto, 1993). Untuk mencapai kondisi fisik yang baik di bidang olahraga dapat diberikan pada masa adolesensi atau saat individu tersebut duduk di tingkat Sekolah Menengah Pertama (SMP), karena kemampuan fisiknya mengalami proses pertumbuhan dan perkembangan.

Observasi dilakukan di SMP Negeri 1 Penebel dengan guru olahraga Bapak I Ketut Arya, S.Pd. Dari hasil observasi dan hasil wawancara dengan guru olahraga di sekolah tersebut dikatakan ada beberapa faktor yang menyebabkan terjadinya fluktuasi dalam cabang bulutangkis di SMP Negeri 1 Penebel diantaranya kurangnya kebugaran fisik pada peserta didik di sekolah tersebut. Kebugaran fisik didefinisikan sebagai, "Kemampuan tubuh dalam melakukan suatu tugas rutin untuk jangka waktu yang cukup lama tanpa mengalami kelelahan dan masih memiliki tenaga cadangan untuk melaksanakan aktivitas yang bersifat mendadak" (N. Nala, 1992)

Saat ekstrakurikuler berlangsung terlihat yang membuat peserta didik ekstrakurikuler bulutangkis melambat ialah saat pengambilan bola kedepan net. Dalam permainan bulutangkis biasanya pada saat melakukan netting atau pengambilan bola di depan net sebagian besar anak-anak malas untuk melangkah maju, itu diakibatkan oleh kondisi fisik anak dalam kecepatan dan daya ledak otot tungkainya kurang. kecepatan dan daya ledak sangat di perlukan dalam semua jenis olahraga khususnya dalam olahraga bulutangkis karena pada saat netting kemampuan otot untuk mengatasi tahanan dengan kontraksi yang sangat cepat melangkah lebar untuk menjaga keseimbangan tubuh. Di dalam suatu pertandingan gerakangerakan tersebut dilakukan berulang-ulang sehingga pemain akan mengalami kelelahan yang mempengaruhi pada permainan, seperti pukulan yang tidak terarah, koordinasi menurun, power yang lemah. Karena itu pemain bulutangkis harus memiliki tingkat kondisi fisik yang baik, melalui pelatihan kondisi fisik yang terprogram dengan baik maka faktor kelelahan akan bisa diatasi. Dengan kata lain, atlet bulutangkis harus memiliki kondisi fisik yang baik agar dalam suatu pertandingan atlet tersebut dapat menjaga konsistensi permainannya.

Terkait dengan hal di atas, maka akan ditawarkan suatu bentuk metode latihan yaitu metode latihan plyometrics untuk membentuk komponen-komponen kondisi fisik terutama 
kecepatan dan daya ledak otot tungkai dan untuk meningkatkan keterampilan teknik netting pada cabang olahraga bulutangkis. Plyometrics adalah latihan-latihan atau ulangan yang bertujuan menghubungkan gerakan kecepatan dan kekuatan untuk menghasilkan gerakangerakan eksplosif (Januar, 2012). Pelatihan playometrik yang cocok untuk permasalahan yang akan diteliti adalah pelatihan scissor jump dan single leg speed hope dimana pelatihan tersebut bertumpu pada berat badan tubuh yang jatuh kedepan pada saat pengambilan bola netting. Scissor jump adalah pelatihan yang bekerja untuk otot punggung bagian bawah extensors pinggul, hamstrings, dan quadriceps. Gerakan awal latihan scissor jump juga sama dengan latihan split jump, puncak loncatan posisi kaki di balik, yaitu kaki depan ke belakang dan kaki belakang ke depan. Pada saat terjadi pergantian kaki di udara dilakukan dengan cepat sebelum mendarat, ulangi lompatan tersebut untuk tungkai kaki yang lain. Lakukan 2-3 set, jumlah ulangan 5-8 kali, dan waktu istirahat kira-kira 2 menit diantara set. Sedangkan pelatihan single leg speed hope merupakan latihan yang mengembangkan kecepatan dan power untuk otot otot tungkai dan pinggul, khususnya kerja otot-otot gluteals, hamstring, quadriceps, dan gastrocnemius dengan kecepatan yang tinggi dan penuh tenaga. Latihan ini dilakukan dengan 1 tungkai kaki. Latihan ini membutuhkan beban lebih untuk otot pinggul, tungkai dan punggung bagian bawah dan juga melibatkan otot otot yang menyeimbangkan lutut. Latihan ini hamper sama dengan latihan doble leg speed hope. Lakukan 2-4 set, jumlah ulangan 8-12 kali untuk tiap kaki. Dan waktu istirahat 2 menit setiap set.

Dilihat dari hal tersebut maka peneliti tertarik mengadakan penelitian dengan dengan tujuan mengetahui pengaruh pelatihan scissor jump dan single leg speed hope dengan tingkat kecepatan berbeda terhadap daya ledak otot tungkai pada peserta ekstrakurikuler bulutangkis SMP Negeri 1 Penebel Tahun Pelajaran 2020/2021".

\section{METODE}

Penelitian ini merupakan jenis penelitian eksperimental semu, tujuan penelitian eksperimental semu adalah untuk memperoleh informasi yang merupakan perkiraan bagi informasi yang dapat diperoleh dengan eksperimen yang sebenarnya dalam keadaan yang tidak memungkinkan untuk mengontrol dan atau memanipulasikan semua variabel yang relevan". (Kanca, 2010) Adapun bentuk pelatihan yang digunakan disini yaitu scissor jump dan single leg speed hope.

Metode penelitian yang digunakan adalah metode eksperimen dengan rancangan factorial 2x2. Pengambilan sampel ini dilakukan dengan cara random sampling. Teknik Random Sampling ini dalam pengambilan sampel, peneliti mencampur subjek-subjek di dalam populasi sehingga memperoleh kesempatan dipilih menjadi sampel. Pengambilan sampel dilakukan dengan membagi populasi menjadi dua kelompok yaitu sebagai kelompok pelatihan scissor jump dan kelompok pelatihan single leg speed hope, kemudian diberikan tes kecepatan dengan instrument sprint test.

Dalam penelitian ini, variabel yang diteliti adalah variable Dependen yaitu variable manipulative yaitu metode latihan yang terdiri dari latihan Scissor jump dan latihan Single leg speed hope. Variable atribut terdiri dari kecepatan awal kategor itinggi dan kecepatan awal kategori rendah serta Variabel Independen. Instrumen penelitian yang digunakan dalam penelitian ini adalah tes vertical jump untuk mengukur daya ledak otot tungkai dan tes lari sprint untuk mengukur kecepatan melangkah kedepan. Data tersebut berupa tes awal (pretest) dan tes akhir (posttest) pada masing-masing kelompok. Tes akhir (posttest) dilaksanakan setelah kelompok perlakukan diberikan pelatihan scissor jump dan single leg speed hope selama 12 kali pelatihan dengan tes yang sama seperti tes awal (pretest). Selanjutnya, dianalisis berdasarkan hasil pengukuran dari masing-masing kelompok.

Uji hipotesis menggunakan uji analisis Varian (ANAVA) dua jalur dengan batuan program spss 16,0 . Hipotesis diterima apabila nilai uji anava dua jalur memiliki nilai signifikansi lebih kecil dari $\alpha($ sig $<0,05)$. Sedangkan apabila nilai signifikansi hitung lebih besar dari $\alpha$ (sig > 0,05), maka hipotesis ditolak (Candiasa, 2010: 119). Bila terdapat perbedaan dilanjutkan dengan uji Tukey untuk mengetahui apakah ada interaksi antara hipotesis pertama dan kedua. 
Jika nilai signifikansi lebih kecil dari $\alpha($ sig $<0,05)$ maka tidak terdapat interaksi antara kedua hipotesis. Sedangkan apabila nilai signifikansi lebih besar dari a (sig > 0,05), maka terdapat interaksi antara kedua hipotesis.

\section{HASIL DAN PEMBAHASAN \\ Hasil}

Penelitian pengaruh pelatihan scissor jump dan pelatihan single leg speed hope dengan tingkat kecepatan terhadap daya ledak otot tungkai pada peserta didik ekstrakurikuler bulutangkis SMP Negeri 1 Penebel yang dilakukan sebanyak 12 kali. Pelatihan dilaksanakan seminggu 3 kali seminggu selama 4 minggu dari tanggal 21 September s/d 17 Oktober 2020. Data skor hasil tes daya ledak otot tungkai peserta didik merupakan data tinggi loncatan yang diperoleh peserta didik peserta didik. Satuan skor dalam hasil penelitian ini adalah centimeter (cm). Rekapitulasi hasil tes daya ledak otot tungkai peserta didik disajikan pada Tabel 1.

Tabel 1.Rekapitulasi Hasil Tes Daya Ledak Otot Tungkai

\begin{tabular}{lccccccc}
\hline \multirow{2}{*}{ Kelompok } & $\begin{array}{c}\text { Jumlah } \\
\text { Sampel }\end{array}$ & $\begin{array}{c}\text { Jumlah } \\
\text { Skor }\end{array}$ & $\begin{array}{c}\text { Rata- } \\
\text { Rata }\end{array}$ & Varians & $\begin{array}{c}\text { Standar } \\
\text { Deviasi }\end{array}$ & Skor Min & $\begin{array}{c}\text { Skor } \\
\text { Max }\end{array}$ \\
\hline Pre A1 & 24 & 1086 & 45,25 & 77,152 & 8,784 & 33 & 63 \\
Post A1 & 24 & 1542 & 64,25 & 75,500 & 8,689 & 50 & 78 \\
Pre A2 & 24 & 1101 & 45,88 & 100,288 & 10,014 & 28 & 60 \\
Post A2 & 24 & 1415 & 58,96 & 36,216 & 6,018 & 50 & 69 \\
Pre B1 & 24 & 1281 & 53,38 & 24,071 & 4,906 & 45 & 63 \\
Post B1 & 24 & 1617 & 67,38 & 41,549 & 6,446 & 54 & 78 \\
Pre B2 & 24 & 906 & 37,75 & 26,196 & 5,118 & 28 & 46 \\
Post B2 & 24 & 1340 & 55,83 & 15,275 & 3,908 & 50 & 63 \\
Pre A1B1 & 12 & 629 & 52,42 & 32,265 & 5,680 & 45 & 63 \\
Post A1B1 & 12 & 861 & 71,75 & 19,114 & 4,372 & 64 & 78 \\
Pre A1B2 & 12 & 457 & 38,08 & 16,992 & 4,122 & 33 & 44 \\
Post A1B2 & 12 & 681 & 56,75 & 16,023 & 4,003 & 50 & 63 \\
Pre A2B1 & 12 & 652 & 54,33 & 16,061 & 4,008 & 48 & 60 \\
Post A2B1 & 12 & 756 & 63,00 & 26,000 & 5,099 & 54 & 69 \\
Pre A2B2 & 12 & 449 & 37,42 & 37,538 & 6,127 & 28 & 46 \\
Post A2B2 & 12 & 659 & 54,92 & 14,083 & 3,753 & 50 & 62 \\
\hline
\end{tabular}

Keterangan :

A1: Latihan Scissor jump

A2: Latihan Single leg speed hope

B1: Tingkat kecepatan Tinggi

B2: Tingkat kecepatan Rendah

\section{Hasil Uji Asumsi}

Dalam pengujian hipotesis secara keseluruhan digunakan analisis deskriptif dan analisis varian (ANAVA) dua jalur. Sebelum dianalisis dengan ANAVA dua jalur, terlebih dahulu diadakan uji asumsi. Uji asumsi pertama yang dilakukan adalah uji normalitas sebaran data dengan formula Komogrov-Smirnov Test dan dengan formula Shapiro-Wilk Test (Santoso, 2017) . Uji asumsi kedua adalah uji homogenitas varians anatar kelompok dengan uji Lenen's Test.

\section{Uji NormalitasData}

Uji normalitas data digunakan untuk keseluruhan unit analisis yaitu kelompok peserta didik yang dilatih dengan metode scissor jump (A1), kelompok peserta didik yang dilatih dengan metode single leg speed hope (A2), kelompok peserta didik yang memiliki tingkat kecepatan tinggi yang dilatih dengan metode scissor jump (A1B1), kelompok peserta didik yang memiliki tingkat kecepatan rendah yang dilatih dengan metode scissor jump (A1B2), kelompok peserta didik yang memiliki tingkat kecepatan tinggi yang dilatih dengan metode single leg speed hope (A2B1) dan kelompok peserta didik yang memiliki tingkat kecepatan rendah yang 
dilatih dengan metode single leg speed hope (A2B2). Uji normalitas sebaran data dalam penelitian ini dilakukan dengan menggunakan statistik Komogorov-Smirnov Test dan ShapiroWilk Test. Data terdistribusi normal jika angka signifikansi yang diperoleh lebih besar dari 0,05 dan jika angka signifikasi lebih kecil dari 0,05 maka data tidak berdistribusi normal. Pengujian normalitas pada penelitian ini berbantuan program SPSS 24.0 for Windows. Berikut ini hasil uji normalitas untuk setiap unit analisis yang ditunjukkan oleh Tabel 2.

Tabel 2. Hasil Uji Normalitas Data

\begin{tabular}{ccccccc}
\hline \multirow{2}{*}{ Variabel } & \multicolumn{3}{c}{ Kolmogorov-Smirnov } & \multicolumn{3}{c}{ Shapiro-Wilk } \\
& Statistik & $d f$ & Sig. & Statistik & $d f$ & Sig. \\
\hline A1 & 0,121 & 24 & $0,200^{*}$ & 0,940 & 24 & 0,165 \\
A2 & 0,147 & 24 & 0,196 & 0,938 & 24 & 0,145 \\
B1 & 0,080 & 24 & $0,200^{*}$ & 0,972 & 24 & 0,722 \\
B2 & 0,108 & 24 & $0,200^{*}$ & 0,951 & 24 & 0,285 \\
A1B1 & 0,113 & 12 & $0,200^{*}$ & 0,951 & 12 & 0,655 \\
A1B2 & 0,125 & 12 & $0,200^{*}$ & 0,975 & 12 & 0,957 \\
A2B1 & 0,153 & 12 & $0,200^{*}$ & 0,914 & 12 & 0,238 \\
A2B2 & 0,136 & 12 & $0,200^{*}$ & 0,953 & 12 & 0,687 \\
\hline
\end{tabular}

Berdasarkan Tabel 2. Terlihat bahwa nilai signifikansi berada di atas 0,05 untuk semua unit analisis, baik dengan menggunakan statistic Komogorov- Smirnov maupun statistic Shapiro-Wilk. Oleh karena itu, semua data yang diperoleh dalam penelitian ini terdistribusi normal.

\section{Uji Homogenitas Varian}

Uji homogenitas dilakukan dengan maksud memberikan informasi bahwa data kelompok sampel berasal dari populasi yang memiliki varian yang sama. Pengujian homogenitas varian antar kelompok dilakukan dengan menggunakan statistik Lenen's Test. Kriteria pengujian yang digunakan adalah data yang memiliki varian yang sama (homogen) jika angka signifikansinya lebih besar dari 0,05 dan data yang memiliki varian yang tidak sama (tidak homogen) apabila angka signifikansinya lebih kecil dari 0,05. Hasil uji homogenitas varians dikelompokkan berdasarkan metode latihan (homogenitas antar metode), tingkat kecepatan (homogenitas antar tingkat kecepatan) serta antara metode dan tingkat kecepatan (homogenitas antar metode dan tingkat kecepatan). Pengelompokan berdasarkan metode pelatihan ditunjukkan oleh Tabel 3, pengelompokan berdasarkan tingkat kecepatan ditunjukkan oleh Tabel 4. dan pengelompokan berdasarkan metode dan tingkat kecepatan ditunjukan oleh Tabel 5

Tabel 3. Hasil Pengujian Homogenitas Varians Antar Metode Pelatihan Daya Ledak Otot tungkai

\begin{tabular}{cccc}
\hline Levene Statistic & $\boldsymbol{d f 1}$ & $\boldsymbol{d f 2}$ & Sig. \\
\hline 3,966 & 1 & 46 & 0,055 \\
\hline
\end{tabular}

Tabel 4. Hasil Pengujian Homogenitas Varians Antar Tingkat Kecepatan

\begin{tabular}{cccc}
\hline \multicolumn{4}{c}{ Daya ledak otot tungkai } \\
\hline Levene Statistic & $\boldsymbol{d f 1}$ & $\boldsymbol{d f 2}$ & Sig. \\
\hline 3,877 & 1 & 46 & 0,067 \\
\hline
\end{tabular}

Tabel 5 Hasil Pengujian Homogenitas Varians Antar Metode dan Tingkat Kecepatan Daya ledak otot tungkai

$\begin{array}{cccc}\text { Levene Statistic } & \boldsymbol{d f 1} & \boldsymbol{d f 2} & \text { Sig. } \\ 0,598 & 3 & 44 & 0,620\end{array}$


Berdasarkan hasil uji homogenitas pada Tabel 3, Tabel 4 dan Tabel 5 data yang diuji bersifat homogen baik untuk varians antar metode latihan, varians antar tingkat kecepatan maupun varians antar metode dan tingkat kecepatan. Hal ini ditunjukkan dengan nilai signifikansi Leven's test yang lebih besar dari 0,05 untuk setiap pengujian homogenitas.

\section{Pengujian Hipotesis}

Pengujian hipotesis secara keseluruhan menggunakan analisis varian (ANAVA) dua jalur, pada taraf signifikansi $5 \%$. Kriteria pengujian yang dilakukan adalah sebagai berikut.

a. Apabila antara $A$ (metode pelatihan) nilai $F$ hitung $>F$ table atau angka signifikansi < 0,05 maka dinyatakan ada perbedaan yang signifikan antar metode pelatihan yang digunakan.

b. Apabila antara B (tingkat kecepatan) nilai $F$ hitung $>F$ table atau angka signifikansi< 0,05 maka dinyatakan ada perbedaan yang signifikan antar tingkat kecepatan.

c. Apabila ada pengaruh interaktif $(A B)$ nilai $F$ hitung $>F$ tabel atau angka signifikansi < 0,05 maka dinyatakan ada pengaruh interaktif antara metode pelatihan dan tingkat kecepatan yang signifikan.

Tabel 6. Hasil Analisis Varian Dua Jalur

\begin{tabular}{|c|c|c|c|c|c|c|c|}
\hline Source & $\begin{array}{l}\text { Type III Sum } \\
\text { of Squares }\end{array}$ & $d f$ & $\begin{array}{l}\text { Mean } \\
\text { Square }\end{array}$ & $F$ & Sig. & $\begin{array}{l}\text { Noncent. } \\
\text { Parameter }\end{array}$ & $\begin{array}{c}\text { Observed } \\
\text { Power }\end{array}$ \\
\hline Corrected Model & $2078,063^{a}$ & 3 & 692,688 & 36,835 & 0,000 & 110,506 & 1,000 \\
\hline Intercept & 182163,521 & 1 & 182163,521 & 9687,012 & 0,000 & 9687,012 & 1,000 \\
\hline Metode Latihan & 336,021 & 1 & 336,021 & 17,869 & 0,000 & 17,869 & 0,985 \\
\hline $\begin{array}{l}\text { Tingkat_- } \\
\text { Kecepatan }\end{array}$ & 1598,521 & 1 & 1598,521 & 85,005 & 0,000 & 85,005 & 1,000 \\
\hline $\begin{array}{l}\text { Metode_Latihan * } \\
\text { Tingkat_ } \\
\text { Kecepatan }\end{array}$ & 143,521 & 1 & 143,521 & 7,632 & 0,008 & 7,632 & 0,771 \\
\hline $\begin{array}{l}\text { Error } \\
\text { Total } \\
\text { Corrected Total }\end{array}$ & $\begin{array}{r}827,417 \\
185069,000 \\
2905,479\end{array}$ & $\begin{array}{l}44 \\
48 \\
47\end{array}$ & 18,805 & & & & \\
\hline
\end{tabular}

a. $R$ Squared $=0,715$ (Adjusted $R$ Squared $=0,696$ )

b. Computed using alpha $=0,05$

\section{Pembahasan \\ Pengaruh Latihan Scissor Jump yang Memiliki Tingkat Kecepatan Tinggi terhadap Peningkatan Daya Ledak Otot Tungkai.}

Pengaruh latihan scissor jump yang memiliki tingkat kecepatan tinggi terhadap peningkatan daya ledak otot tungkai berdasarkan analisis deskriftif menunjukkan terdapat pengaruh latihan scissor jump yang memiliki tingkat kecepatan tinggi terhadap peningkatan daya ledak otot tungkai. Dilihat dari selisih rata-rata antara pre test dan post test pada peserta didik dengan tingkat kecepatan tinggi yang latihan dengan metode scissor jump juga mempunyai selisih rata-rata sebesar 19,33 yang merupakan selisih yang cukup jauh. Kelompok peserta didik yang memiliki kecepatan tinggi dan diterapkan latihan scissor jump memperoleh nilai rata-rata terestimasi peningkatan daya ledak otot tungkai sebesar 71,750 yang merupakan rata-rata paling unggul dibandingkan kelompok lainnya. Hal ini karena kemampuan awal yang dimiliki peserta didik berupa kecepatan tinggi sudah unggul dimana kemampuan tubuh untuk bergerak secara singkat dan secepat mungkin telah dimiliki oleh kelompok peserta didik dengan kecepatan tinggi sehingga ketika dilatihkan melalui latihan scissor jump yang merupakan pelatihan yang bekerja untuk otot punggung bagian bawah extensor pinggul, hamstrings dan quadriceps menghasilkan hasil yang maksimal dan optimal. 
Kelompok peserta didik dengan kecepatan tinggi menjadi unggul karena dilatihkan dengan teknik pelatihan yang tepat yaitu melalui teknik pelatihan scissor jump dimana pelatihan ini bekerja untuk otot punggung bagian bawah extensors pinggul, hamstrings dan quadriceps sehingga kemampuan daya ledak otot menjadi optimal karena tahapan latihan seperti pada posisi awal salah satu kaki ditekuk kedepan dan kaki satunya agak menekuk kebelakang, posisi tangan berada di pinggang. Kemudian mengambil ancang-ancang meloncat dengan posisi berdiri melayang di udara. Selanjutnya pada posisi melayang di udara kaki bertukar posisi sebelum mendarat dan pada posisi mendarat posisi akhir sikap scissor jump dengan bertukar tumpu kaki. Latihan tersebut meningkatkan daya ledak otot tungkai dan kecepatan yang dibutuhkan dalam permainan bulu tangkis.

\section{Pengaruh Latihan Scissor Jump yang Memiliki Tingkat Kecepatan Rendah terhadap Peningkatan Daya Ledak Otot Tungkai.}

Pengaruh latihan scissor jump yang memiliki tingkat kecepatan rendah terhadap peningkatan daya ledak otot tungkai berdasarkan analisis deskriptif menunjukkan terdapat pengaruh latihan scissor jump yang memiliki tingkat kecepatan rendah terhadap peningkatan daya ledak otot tungkai. Dilihat dari selisih rata-rata antara pre test dan post test pada peserta didik dengan tingkat kecepatan rendah yang latihan dengan metode scissor jump juga mempunyai selisih rata-rata sebesar 18,67 yang merupakan selisih yang cukup jauh. Kelompok peserta didik yang memiliki kecepatan rendah dan diterapkan latihan scissor jump memperoleh nilai rata-rata terestimasi peningkatan daya ledak otot tungkai sebesar 56,750 yang merupakan rata-rata peringkat keunggulan nomor tiga dibandingkan kelompok lainnya. Hal ini karena kemampuan awal berupa kecepatan yang dimiliki masih rendah, sehingga dalam pelatihan menghasilkan hasil yang belum optimal.

Kecepatan merupakan komponen penting untuk menghasilkan daya ledak otot tungkai yang optimal dan dalam permainan bulu tangkis kecepatan merupakan kemampuan yang harus dimiliki sebab untuk bisa memasukkan shuttlecock ke bidang lawan, kecepatan dan kekuatan kaki menjadi peran penting, disamping kekuatan pukulan. Oleh karena itu daya ledak otot tungkai yaitu kekuatan komponen otot yang ditandai dengan gerakan tiba-tiba dalam waktu sang singkat dan cepat dalam mengatasi beban yang diterima akan optimal apabila kecepatan yang dimiliki optimal.

\section{Pengaruh Latihan Single Leg Speed Hope yang Memiliki Tingkat Kecepatan Tinggi terhadap Peningkata Daya Ledak Otot Tungkai}

Pengaruh latihan single leg speed hope yang memiliki tingkat kecepatan tinggi terhadap peningkatan daya ledak otot tungkai berdasarkan analisis deskriptif menunjukkan terdapat pengaruh latihan single leg speed hope yang memiliki tingkat kecepatan tinggi terhadap peningkatan daya ledak otot tungkai. Dilihat dari selisih rata-rata antara pre test dan post test pada peserta didik dengan tingkat kecepatan tinggi yang latihan dengan metode single leg speed hope juga mempunyai selisih rata-rata sebesar 8,67 yang merupakan selisih yang cukup jauh. Kelompok peserta didik yang memiliki kecepatan tinggi dan diterapkan latihan single leg speed hope memperoleh nilai rata-rata terestimasi peningkatan daya ledak otot tungkai sebesar 63,000 yang merupakan rata-rata unggul nomor dua dibandingkan kelompok lainnya.

Hal ini karena kemampuan awal yang baik seperti kecepatan tinggi tidak akan berkembang maksimal apabila tidak diiringi penerapan latihan yang tepat. Pada latihan dengan single leg speed hope dengan tahapan awal yaitu sikap berdiri dengan satu tungkai kaki dan satunya ditekuk, keseimbangan diatur sedemikian rupa. Selanjutnya tubuh rileks, pandangan ke depan dan bahu sedikit condong kedepan, Ialu mulai meloncat keatas setinggi mungkin dan memberi tekanan pada angkatan maksimum dengan membawa lutut keatas dan kedepan pada tiap ulangan. Hal ini belum mampu memaksimalkan kecepatan dan power untuk otot-otot tungkai dan pinggul, khususnya kerja otot-otot gluteals, hamstring, quadriceps dan gastrocnemius dengan kecepatan tinggi dan penuh tenaga. 


\section{Pengaruh Latihan Single Leg Speed Hope yang Memiliki Tingkat Kecepatan Rendah terhadap Peningkatan Daya Ledak Otot Tungkai}

Pengaruh latihan single leg speed hope yang memiliki tingkat kecepatan rendah terhadap peningkatan daya ledak otot tungkai berdasarkan analisis deskriptif menunjukkan terdapat pengaruh latihan single leg speed hope yang memiliki tingkat kecepatan rendah terhadap peningkatan daya ledak otot tungkai. Dilihat dari selisih rata-rata antara pre test dan post test pada peserta didik dengan tingkat kecepatan rendah yang latihan dengan metode single leg speed hope juga mempunyai selisih rata-rata sebesar 17,50 yang merupakan selisih yang cukup jauh. Kelompok peserta didik yang memiliki kecepatan rendah dan diterapkan latihan single leg speed hope memperoleh nilai rata-rata terestimasi peningkatan daya ledak otot tungkai sebesar 54,917 yang merupakan rata-rata terendah dibandingkan kelompok lainnya.Hal ini karena kemampuan awal yang lemah yaitu tingkat kecepatan yang rendah diterapkan metode latihan yang tidak tepat menghasilkan kemampuan daya ledak otot tungkai kaki yang tidak optimal.

Hasil penelitian ini sejalan dengan yang dilakukan oleh(Arisman et al., 2018) pelatihan single leg speed hope memberikan pengaruh terhadap daya ledak otot tungkai dan penelitian oleh (KARTIKO, 2005) yang menyatakan peserta dengan kelincahan atau kecepatan tinggi menghasilkan daya ledak otot yang lebih baik dibandingkan peserta dengan kelincahan atau kecepatan rendah.

\section{Perbedaan antara Pengaruh Latihan Scissor Jump yang Memiliki Tingkat Kecepatan Tinggi dan Rendah terhadap Peningkatan Daya Ledak Otot Tungkai.}

Pengaruh latihan scissor jump yang pada peserta yang memiliki tingkat kecepatan tinggi dan rendah terhadap peningkatan daya ledak otot tungkai menunjukkan adanya perbedaan daya ledak otot tungkai antara kelompok yang memiliki tingkat kecepatan tinggi dan tingkat kecepatan rendah berdasarkan uji HSD yang merupakan uji lanjutan dari analisis varian dua jalur, kelompok yang memiliki kecepatan tinggi memperoleh nilai rata-rata terestimasi daya ledak otot tungkai yang lebih unggul sebesar 15,000 dibandingkan kelompok yang memiliki kecepatan rendah. Nilai signifikansi sebesar 0,000 yang lebih kecil dari 0,05 berarti perbedaan daya ledak otot tungkai antara kelompok yang memiliki tingkat kecepatan tinggi yang diterapkan latihan scissor jump dan kelompok yang memiliki tingkat kecepatan rendah yang diterapkan latihan scissor jump bersifat signifikan.

Hal ini karena kemampuan awal yang dimiliki telah berbeda meskipun diterapkan metode latihan yang sama dengan waktu dan kuantitas latihan yang sama maka hasil yang diberikan berbeda. Kelompok peserta didik dengan kecepatan tinggi telah memiliki keunggulan dibandingkan kelompok dengan kecepatan rendah. Ketika diterapkan metode yang sama yaitu metode scissor jump maka kelompok yang memiliki keunggulan kecepatan tinggi tentu memiliki daya ledak otot tungkai yang lebih tinggi. Hasil penelitian ini relevan dengan hasil penelitian (KARTIKO, 2005) yang menyatakan peserta dengan kelincahan atau kecepatan tinggi menghasilkan daya ledak otot yang lebih baik dibandingkan peserta dengan kelincahan atau kecepatan rendah.

\section{Perbedaan antara Pengaruh Latihan Single Leg Speed Hope yang Memiliki Tingkat Kecepatan Tinggi dan Rendah terhadap Peningkatan Daya Ledak Otot Tungkai}

Pengaruh latihan single leg speed hope pada peserta yang memiliki tingkat kecepatan tinggi dan rendah terhadap peningkatan daya ledak otot tungkai menunjukkan adanya perbedaan daya ledak otot tungkai antara kelompok yang memiliki tingkat kecepatan tinggi dan tingkat kecepatan rendah berdasarkan hasil uji HSD yang merupakan uji lanjutan dari analisis varian dua jalur. Kelompok yang memiliki kecepatan tinggi memperoleh nilai rata-rata terestimasi daya ledak otot tungkai yang lebih unggul sebesar 8,083 dibandingkan kelompok yang memiliki kecepatan rendah. Nilai signifikansi sebesar 0,000 yang lebih kecil dari 0,05 berarti perbedaan daya ledak otot tungkai antara kelompok yang memiliki kemampuan awal 
tinggi yang diterapkan latihan single leg speed hope dan kelompok yang memiliki kecepatan rendah yang diterapkan latihan single leg speed hope bersifat signifikan.

Hal ini karena kemampuan awal yang dimiliki telah berbeda meskipun diterapkan metode latihan yang sama dengan waktu dan kuantitas latihan yang sama maka hasil yang diberikan berbeda. Kelompok peserta didik dengan kecepatan tinggi telah memiliki keunggulan dibandingkan kelompok dengan kecepatan rendah. Ketika diterapkan metode yang sama yaitu metode single leg speed hope maka kelompok yang memiliki keunggulan kecepatan tinggi tentu memiliki daya ledak otot tungkai yang lebih tinggi. Meskipun penerapan latihan single leg speed hope tidak lebih unggul dibandingkan latihan scissor jump dalam meningkatkan daya ledak otot tungkai.

\section{Interaksi antara Latihan Scissor Jump yang Memiliki Tingkat Kecepatan Tinggi dan Rendah dengan Latihan Single Leg Speed Hope yang Memiliki Tingkat Kecepatan Tinggi dan Rendah terhadap Peningkatan Daya Ledak Otot Tungkai.}

Hasil pengujian pengaruh interaksi antara latihan scissor jump yang memiliki tingkat kecepatan tinggi dan rendah dengan latihan single leg speed hope yang memiliki tingkat kecepatan tinggi dan rendah terhadap peningkatan daya ledak otot tungkai berdasarkan analisis varian dua jalur yang menunjukkan terdapat interaksi antara latihan scissor jump yang memiliki tingkat kecepatan tinggi dan rendah dengan latihan single leg speed hope yang memiliki tingkat kecepatan tinggi dan rendah terhadap peningkatan daya ledak otot tungkai yang diperoleh berdasarkan nilai $F$ sebesar 7,632 dan nilai signifikansi 0,008 yang lebih kecil dari 0,05 sehingga hipotesis $\mathrm{H}_{0}$ ditolak dan $\mathrm{H}_{\mathrm{A}}$ diterima.

Daya ledak otot tungkai yang merupakan kemampuan atau kekuatan komponen otot yang ditandai dengan gerakan tiba-tiba dalam waktu yang singkat dan cepat dalam mengatasi beban yang diterima hanya akan dicapai maksimal oleh kelompok yang memiliki kecepatan tinggi yaitu kemampuan tubuh untuk bergerak sesingkat-singkatnya dengan secepat mungkin. Komponen daya ledak otot tungkai dan kecepatan sangat berperan penting dalam permainan bulu tangkis untuk dapat memasukkan shuttlecock ke bidang permainan lawan melalui net agar shuttlecock tidak bisa dikembalikan lagi.

Penerapan metode latihan yang unggul dan tepat pada kelompok yang memiliki kecepatan tinggi akan memberikan kemampuan daya ledak otot yang optimal, hal ini karena kemampuan khususnya kecepatan tinggi diasah dengan baik melalui pelatihan yang tepat. Hal ini dapat dilihat berdasarkan hasil penelitian dimana kelompok yang diterapkan latihan scissor jump dengan kecepatan tinggi memiliki rata-rata yang paling unggul yaitu sebesar 71,750 dibandingkan kelompok lainnya seperti kelompok yang diterapkan latihan leg speed hope dengan kecepatan tinggi memperoleh rata-rata daya ledak otot sebesar 63,000 yang merupakan peringkat unggul nomor dua. Selanjutnya kelompok yang diterapkan latihan scissor jump yang memiliki kecepatan rendah memiliki rata-rata sebesar 56,750 yang menduduki peringkat unggul nomor tiga dan kelompok yang diterapkan latihan single leg speed hope dengan kecepatan rendah memperoleh rata-rata yang paling rendah yaitu sebesar 54,917. Sehingga, penerapan metode latihan yang tepat dan optimal yaitu scissor jump terhadap kemampuan kecepatan yang tinggi akan menghasilkan daya ledak otot tungkai yang optimal dibandingkan kelompok lainnya.

Hasil penelitian ini sejalan dengan hasil penelitian(Dewi et al., 2018) yang menyatakan pelatihan single leg speed hope memberikan pengaruh terhadap daya ledak otot tungkai dan selaras juga dengan penelitian penelitian. Selaras dengan penelitian(KARTIKO, 2005) yang menyatakan peserta dengan kelincahan atau kecepatan tinggi menghasilkan daya ledak otot yang lebih baik dibandingkan peserta dengan kelincahan atau kecepatan rendah. 


\section{SIMPULAN DAN SARAN Simpulan}

Adapun kesimpulan dari penelitian ini yaitu terdapat pengaruh latihan scissor jump yang memiliki tingkat kecepatan tinggi terhadap peningkatan daya ledak otot tungkai. Terdapat pengaruh latihan scissor jump yang memiliki tingkat kecepatan rendah terhadap peningkatan daya ledak otot tungkai. Terdapat pengaruh latihan single leg speed hope yang memiliki tingkat kecepatan tinggi terhadap peningkatan daya ledak otot tungkai. Terdapat pengaruh latihan single leg speed hope yang memiliki tingkat kecepatan rendah terhadap peningkatan daya ledak otot tungkai. Terdapat interaksi antara latihan scissor jump yang memiliki tingkat kecepatan tinggi dan rendah dengan latihan single leg speed hope yang memiliki tingkat kecepatan tinggi dan rendah terhadap peningkatan daya ledak otot tungkai. Pelatihan scissor jump lebih unggul diterapkan terhadap level kecepatan dalam pencapaian daya ledak otot tungkai dibandingkan pelatihan single leg speed hope. Terdapat perbedaan antara pengaruh latihan scissor jump yang memiliki tingkat kecepatan tinggi dan rendah terhadap peningkatan daya ledak otot tungkai. Terdapat perbedaan antara pengaruh latihan single leg speed hope yang memiliki tingkat kecepatan tinggi dan rendah terhadap peningkatan daya ledak otot tungkai.

\section{Saran}

Adapun saran dari hasil penelitian ini yaitu perlu diadakannya penerapan pelatihan menggunakan latihan scissor jump dengan tingkat kecepatan tinggi untuk meningkatkan kekuatan otot dan daya ledak otot tungkai. Pelatihan scissor jump perlu dilaksanakan dengan disiplin dan konsistensi untuk mendapatkan hasil yang optimal. Perlu diadakannya tes kemampuan awal untuk mengetahui tindak lanjut seperti pemberian materi dan kegiatan prapelatihan untuk memupuk pengetahuan atau kemampuan awal peserta yang memiliki kecepatan rendah, sehingga dalam proses pelatihan tidak terdapat kesenjangan antara peserta dengan kecepatan tinggi dan kecepatan rendah.

\section{DAFTARPUSTAKA}

Arisman, A., Saripin, S., \& Vai, A. (2018). Hubungan kelentukan pergelangan tangan dan power otot lengan-bahu dengan hasil akurasi smash bulutangkis putra pada PB. Angkasa Pekanbaru. Journal Of Sport Education (JOPE), 1(1), 9-16.

Dewi, N. K. R., Sudiana, I. K., \& Arsani, N. L. K. A. (2018). Pengaruh Pelatihan Single Leg Speed Hop dan Double Leg Speed Hop Terhadap Daya Ledak Otot Tungkai. Jurnal IImu Keolahragaan Undiksha, 6(3), 1-10.

Januar, A. (2012). Dampak Penerapan Pelatihan Komplex Training Terhadap Peningkatan Kemampuan Speed. Diakses Tanggal, 17.

Kanca, I. N. (2010). Metode Penelitian Pengajaran Pendidikan Jasmani dan Olahraga. Singaraja: Universitas Pendidikan Ganesha.

KARTIKO, D. W. I. C. (2005). BEDA PENGARUH LATIHAN PLIOMETRIK KONVENSIONAL DAN MODTFIKASI TERHADAP DAYA LEDAK OTOT DAN KELINCAHAN. UNIVERSITAS AIRLANGGA.

Nala, I. G. N. (2011). Prinsip Pelatihan Fisik Olahraga Denpasar. Universitas Udayana.

Nala, N. (1992). Kumpulan Tulisan Olahraga. Denpasar: KONI Bali.

Santoso, S. (2017). Statistik multivariat dengan SPSS. Elex Media Komputindo.

Sugiyanto, S. (1993). Perkembangan dan Belajar Gerak. Jakarta: Departemen Pendidikan Dan Kebudayaan. 